\title{
Isolation, Identification and Antibiotic Susceptibility Pattern of Bacteria Isolated from Wounds of Patients Attending at Arsho Advanced Medical Laboratory
}

\author{
Messele Admassie, Estifanos Tsige, Meseret Chanie \\ Department of Microbiology, Arsho Advanced Medical Laboratory, Addis Ababa, Ethiopia \\ Email address: \\ Mesele2006@gmail.com(M. Admassie),tsigeestifanos@gmail.com(E. Tsige), chaniemeseret@gmail.com(M. Chanie) \\ To cite this article: \\ Messele Admassie, Estifanos Tsige, Meseret Chanie. Isolation, Identification and Antibiotic Susceptibility Pattern of Bacteria Isolated from \\ Wounds of Patients Attending at Arsho Advanced Medical Laboratory. Science Journal of Clinical Medicine. Vol. 7, No. 2, 2018 , pp. $20-24$. \\ doi: $10.11648 /$ j.sjcm.20180702.12
}

Received: March 9, 2018; Accepted: April 2, 2018; Published: May 11, 2018

\begin{abstract}
Wound infections cause clinical and societal consequences on the patients, but its bacteriological characteristicvaries with different factors. Therefore, effective treatment and management of wound infections in hospital and communitysetting will require detailed epidemiological knowledge of the infecting bacterial pathogens and their antibiogramunusual to theenvironment. Based on this information, we examined the frequency and antibiogram of bacterial pathogens isolated from woundinfection cases seen at ArshoAdvancedmedical laboratory over the study period. A total of 259 wound swabs/ and pus of different types of woundinfections from different anatomical sites were analyzed by standard bacteriological methods. Of the 259 clinical specimens analyzed, $177(68.4 \%)$ yielded at least one bacterial pathogens, $6(2.3 \%)$ were polymicrobial, and $82(31.6 \%)$ yielded no bacterial growth. Overall, 20 different bacterial pathogens were identified 15 (75\%) gram-negative bacteria isolates and 5(25\%) gram-positive bacterial isolated. Staphylococcus aureus accounted formajority of the bacterial pathogens isolated, 86 (48.6\% followed by E.coli20 (11.3\%, and Citrobacterspp. 17(9.6\%). The bacterial pathogens demonstrated high resistance to amoxicillin $(79.7 \% \%)$, ampicillin $(78.3 \%)$, and tetracycline $(73.1 \%)$, in contrastto high sensitivity pattern observed with Meropinem (94.5\%), Levofloxacin (87\%), Amikacin (82.4\%), and Ceftazidime (72.7\%). Amikacin, meropenem and levofloxacin were the most effective drugs against the tested gram- positive and -negative bacteria and should be considered in empirical antibiotic selection.
\end{abstract}

Keywords: Wound Infections, Bacterial Pathogens, Polymicrobial, Arsho

\section{Introduction}

Skin is one of our innate immunity that prevents infections of subcutaneous and systemic tissues physically and through the production of sweat and sebaceous secretions that provide protection by a virtue of their acid $\mathrm{pH}$ (3-5) and chemicals such asfatty acids and lysozyme that has antifungal property and dissolves bacterial cell respectively. Wound is abreach in the skin and the exposure ofsubcutaneous tissues following loss of skin integrity which provides a moist, warm, and conducive environment that is conducive to microbial colonization and proliferation [1].

Infection of the wound is the successful invasion, and proliferation by one or more organisms anywhere within the body's sterile tissues, sometimes resulting in pus formation
[1]. Wounds can be classified as accidental, pathological or post-operative. Whatever the nature of the wound, infection is the attachment of microorganisms to host cells and they proliferate, colonize and become better placed to cause damage to the host tissues [2].

A wound can be considered infected if purulent material is observed without confirmation of a positive culture. The numbers of contaminants may not persist but specifically grow and divide and may become established, causing wound colonization or infection. Infection in a wound delays healing and may cause wound breakdown, herniation of the wound and complete wound dehiscence [3].

Most commonly isolated aerobic microorganism include 
Staphylococcusaureus, Coagulase-negative staphylococci (CoNS), Enterococci, Escherichia coli, Pseudomonasaeruginosa, Klebsiellapneumoniae, Enterobacter species, Proteus mirabilis, Candida albicansandAcinetobacter [1].

The control of wound infections has become more challenging due to widespread bacterial resistance to antibiotics and to a greater incidence of infections caused by methicillin-resistant $S$. aureus, polymicrobic flora and by fungi [4]. Wound infections have been a problem in the field of medicine for a long time. Apparent shift in the etiological agents of wound infection and the associated problem of antibiotic resistance amongst bacteria that cause wound infection from time to time and from one institution to another has initiated health institution to carry out continuous routine evaluation of would infection from the view point of their spectrum and drug susceptibility testing. The widespread uses of antibiotics, together with the length of time over which they have been available, have led to the emergence of resistant bacteria pathogens contributing to morbidity and mortality [5].

This study was aimed todetermine thefrequency and antibacterial susceptibilityof bacteria isolated from wound infectionsin patients referred to ArshoAdvanced medical laboratory, Addis Ababa, Ethiopia. As well as updates the clinicians in the variousantimicrobial alternatives available in thetreatment of wound infections.

\section{Objectives}

\subsection{General Objectives}

To determine the frequency, bacterial outline and antibiotic susceptibility pattern of isolated from wound infection at Arsho advanced medical laboratory.

\subsection{Specific Objectives}

To assess the bacterial pathogens responsible for the wound infection

To verify the antimicrobial resistance and sensitivity pattern of commonly isolated wound microbes

\section{Materials and Methods}

\subsection{Study Site and Period}

Wound samples were collected from the 259 patients on different days at the microbiology department of ArshoAdvanced Medical laboratory, Addis Ababa, Ethiopia fromJanuary to June 2016. The woundsamples were collected by using a sterile cotton swab, and then the swabs were transported with Amies transport media to the micro biology laboratory.

\subsection{Sample Collection and Inoculation of Primary Isolation Culture Media}

Up on admission to the study, wound specimens were collected aseptically from the study participants using sterile rayon tipped applicator stick swabs. Wound swabs collected from each patient was inoculated onto blood agar base to which $10 \%$ sheep blood is incorporated and macConkey agar. If a delay in culture was unavoidable wound swabs were transported to the laboratory by using Amies transport medium. Preparation and performance of evaluation of culture media were done as per the instruction of the manufacturer.

\subsection{Bacterial Identification}

Pure isolates of bacterial pathogen were preliminary characterized by colony morphology, hemolytic reaction on blood agar medium, gram-stain and catalase test. Identification of bacteria down to genus and/or species level was done by employing an array of routine biochemical tests such as DNASe, catalase, optochin, bacitracin, CAMP, bile esculine tests for gram positive bacteria and Indole production, $\mathrm{H}_{2} \mathrm{~S}$ production, gas production, motility, urease, citrate utilization tests and fermentation of different carbohydrates for gram negative bacteria and signed by family member and/or adult guardian for participants under the age of 18 years.

\subsection{Bacterial Analysis}

The wound swab/pus specimens were inoculated on Blood agar and MacConkey plates, incubated at $37^{\circ} \mathrm{C}$ for 24 hours. Suspected bacterial colonies were identified by standard bacteriological methods [6]. Antimicrobial susceptibility testing was carried out by disc diffusion method on MuellerHinton agar [7]. The following antibiotic discs were tested, Amicacin, penicillin, ampicillin, amoxicillin, Ciprofloxacin, erythromycin, augmentin, gentamycin, Cefalotin, ceftazidime, Ceftriaxone, Cefotaxime, Cefepime, Ciprofloxacin, Clarithromycin, Clinidamycin, Cloxacillin, Cotrimoxazole, chloramphenicol, Doxycillin, Erythromycin, Kanamycin, Levofloxacin, meropinem, Naldixic, Nitrofurantin, Norfloxacin, Penicillin, and Tetracycline. The data were analyzed using SPSS version 20. Values expressed in mean and percentages.

\section{Ethical Clearances}

All ethical considerations and obligations were duly addressed and the study was conducted after the approval of the Internal Review Board (IRB) Arsho Advanced Medical Laboratory PLC. Informed written consent was obtained from participants before data collection. The respondent was given the right to refuse to take part in the study and to withdraw at any time during the study period. All the information obtained from the study subjects were coded to remain confidentially. When the participants were found to be positive for bacterial pathogen, they were informed by the hospital clinician and received proper treatment. 


\section{Result}

Of the 259 wound specimens examined, 177(68.4\%) yielded at least one bacterial pathogens, 6(2.3\%) were polymicrobial (mainly S.aureus and Citrobacter spp.), and $82(31.6 \%)$ cases with no bacterial pathogens isolated.

Overall, 20 different bacterial pathogens were isolated, 15 (75\%) gram-negative bacteria and $5(25 \%)$ gram-positive bacteriapathogen. The frequency of bacterialpathogens isolated, S.aureus accounted for $48.6 \%$ of the total pathogens isolated, followed by E.coli 11.3\%, Citrobacterspp., 9.6\%, Proteus and Pseudomonas spp. 5.1\% Coagulase negative Staphylococcus 3.9\%, Providenciarettgri 3.4\%, Acinitobacter spp. 2.8\%, E.fecalis, Entrobacter cloacae, k.pneumonia and k. oxytoca $1.7 \%$, Staphylococcus hominis $1.13 \%$, S.milliris, Entrobacteraerogens, Edwardsiellaspp and Morganellamorgani accounted for $1 \%$ each respectively.

Antimicrobial susceptibility pattern of the bacterial pathogens as presented in table 1, showed high sensitivity to meropinem (94.5\%), levofloxacin (87\%), amikacin $(82.4 \%)$, cftizadime (for pseudomonas) (72.7\%), vancomycin (71.4) and reduced sensitivity to amoxicillin $(20.3 \%)$, ampicillin $(21.7 \%)$, doxycillin $(23.2 \%)$, teteracycline $(26.9 \%)$, naldixic $(32.2 \%)$ and co-trimoxazole $(42.7 \%)$. Frequency of bacterial pathogen was demonstrated in figure 1; gram positive bacteria exhibiting relatively high sensitivity pattern compared to gram negative bacteria

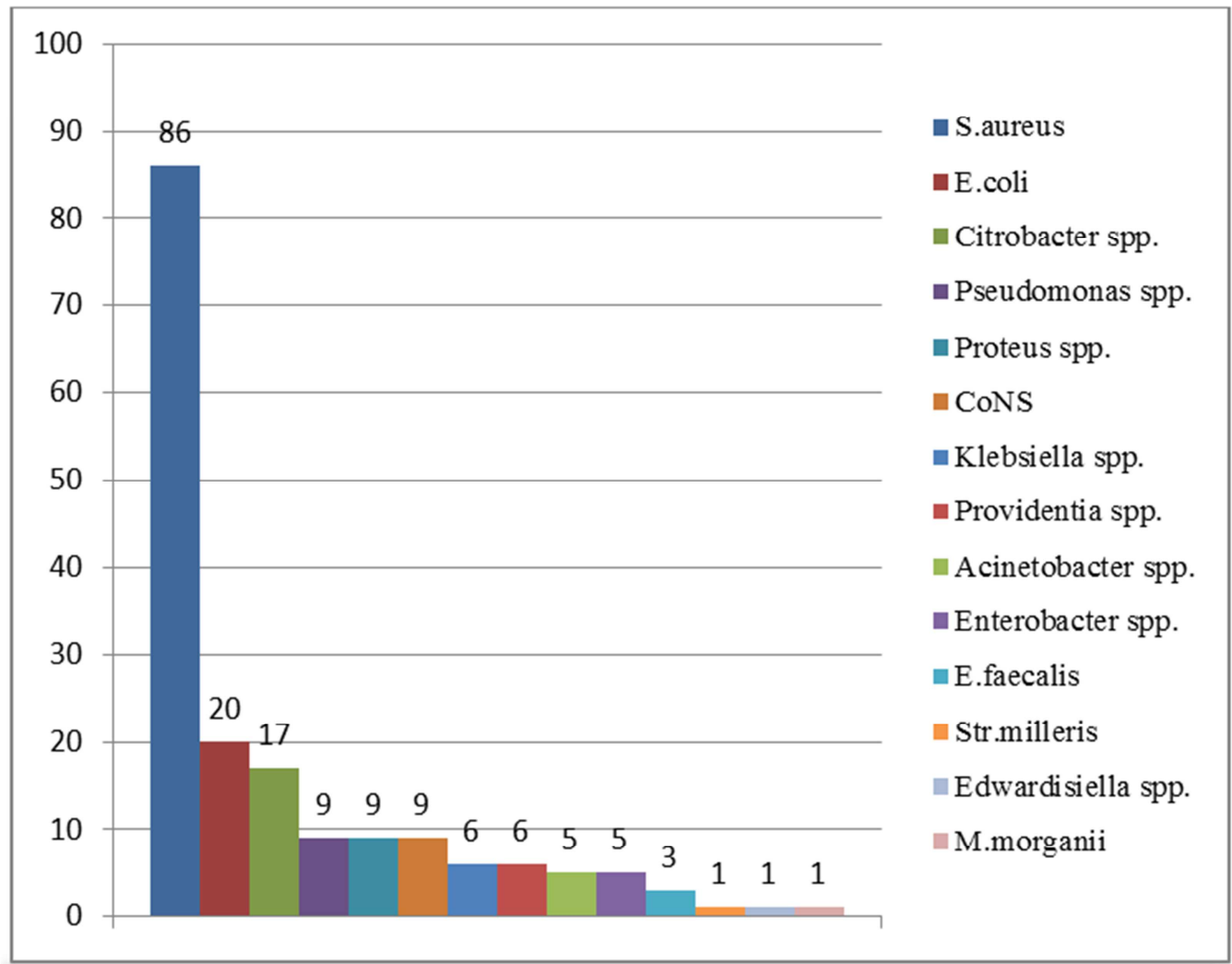

Figure 1. Frequency of isolation of bacterial pathogens.

Table 1. Overall Antimicrobial susceptibility pattern of bacterial pathogens isolated.

\begin{tabular}{llll}
\hline No & $\begin{array}{l}\text { Antimicrobial agents } \\
\text { tested }\end{array}$ & Sensitivity (\%) & Resistance (\%) \\
\hline 1 & Amikacin & $82.4 \%$ & $17.6 \%$ \\
2 & Amoxicilline & $20.3 \%$ & $79.7 \%$ \\
3 & Ampicillin & $21.7 \%$ & $78.3 \%$ \\
4 & Augumentin & $50 \%$ & $50 \%$ \\
5 & Cefalotin & $44 \%$ & $56 \%$ \\
6 & Ceftazidime & $72.7 \%$ & $27.3 \%$ \\
7 & Ceftriaxone & $61.9 \%$ & $38.1 \%$ \\
8 & Cefotaxime & $61.5 \%$ & $38.5 \%$ \\
9 & Cefepime & $68.1 \%$ & 31.9 \\
10 & Ciprofloxacin & $62.7 \%$ & $37.3 \%$ \\
11 & Chloroamphenicol & $63.2 \%$ & $36.8 \%$ \\
12 & Clarithromycin & $62.3 \%$ & $37.7 \%$ \\
\hline
\end{tabular}

\begin{tabular}{llll}
\hline No & $\begin{array}{l}\text { Antimicrobial agents } \\
\text { tested }\end{array}$ & Sensitivity (\%) & Resistance (\%) \\
\hline 13 & Clinidamycin & $54.6 \%$ & $45.4 \%$ \\
14 & Cloxacillin & $42.7 \%$ & $57.3 \%$ \\
15 & Co-trimoxazole & $69 \%$ & $31 \%$ \\
16 & Doxycycline & $23.2 \%$ & $76.8 \%$ \\
17 & Erythromycin & $66.2 \%$ & $33.8 \%$ \\
18 & Gentamycin & $66 \%$ & $34 \%$ \\
19 & Kanamycin & $52.6 \%$ & $47.4 \%$ \\
20 & Levofloxacin & $87 \%$ & $13 \%$ \\
21 & Meropinem & $94.5 \%$ & $5.5 \%$ \\
22 & Naldixic acid & $32.2 \%$ & $67.8 \%$ \\
23 & Nitrofurantoin & $60 \%$ & $40 \%$ \\
24 & Norfloxacin & $48.9 \%$ & $51.1 \%$ \\
25 & Penicillin & $57.5 \%$ & $42.5 \%$ \\
26 & Teteracyclin & $26.9 \%$ & $73.1 \%$ \\
\hline
\end{tabular}




\section{Discussions}

Among the culture reports obtained, the most common organism was found to be Staphylococcus aureus (48.6\%). Similarly, the previous studies done in various parts of India has shown a higher frequency of staphylococcus aureus (39\%) isolates from pus culture reports [8]. The results obtained from Arsho advanced medical laboratory, Staphylococcus aureus was the predominant organism isolated from wound culture and showed high sensitivity to Meropenem, Levofloxacin, Amicacin, and Cefepime which was similar to the previous results of $[9,10]$. Wound infections serve as favorable medium for proliferation of microorganisms that are potentially pathogenic. In most wound infection studies, polymicrobial is a common phenomenon, in this study we reported a polymicrobial rate of $2.3 \%$ which is lower compared to $18.6 \%$ reported in a study in Ethiopia [11]. Similarly, relatively few numbers of bacterial pathogens were isolated. The reason for this few number recorded may be due to, (i). Quality of clinical specimens collected, (ii). Delay in the transportation of the clinical specimens from the branchesc/hospitals to the laboratory, (iii). Laboratory methods employed and (IV) possible preantimicrobial medication by the patients.

The frequency of bacterial isolation recorded in this study showed that gram-negative bacteria accounted for $75 \%$ as against $25 \%$ of gram positive bacteria. Similarly, in Nigeria gram negative bacteria accounted for $70 \%$ as against 305 gram positive bacteria [11].

In the breakdown of bacterial pathogens isolated, S.aureus isolates predominates, followed by E.coli, and Citrobacterspp, which is contrary to the pattern reported in some studies and varies with the frequency of isolation [12-14], but similar result was revealed by [15].

While other studies have reported pathogens like Pseudomonas aeruginosa, Klebsiellaspp and E.coli as leading pathogens in different wound infections and geographical locations $[16,17]$.

Ageneral overview of the anti biogram of all the bacterial isolates indicated that both the Gram positive bacteriaand Gram negative bacteria had very high resistance levels. This situation raises serious concern. This suggests avery high resistance gene pool due to gross misuse and inappropriate usage of the antibacterial agents. The increase in the antibiotic resistance noticed in this study is in agreement with an earlier report by [18]. Where antibiotic mistreatment and high incidence of self medication with antibiotics were identifiedas being responsible for the selection of antibiotic resistant bacterial strains.

\section{Limitation of the Study}

It was not possible to include anaerobic bacteria due to unfortunate laboratory facilities constraints.

\section{Conclusion}

The findings of this study suggest that bacterial resistance in wound infections is becoming serious threat in the study area. Staphylococcus aureusis still the most frequently involved pathogen, showing high resistance rates of bacteria isolated from wounds followed by E.coli, Citrobacterspp, and the least occurring Edwardsiella spp and Morganella morgani. Amicacin and Meropinemare the best therapeutic options from the results (table 1) to treat Staphylococcal infections because of the lesser resistance caused by these organisms and also for Gram negative isolates.

Infections of the wound by these bacteria are one of the most common and important cause of morbidityand mortality in developing countries. The delay in recovery and subsequent increased length of hospital stayalso has economic consequences. The most commonly prescribed antibiotics in the facility were the penicillins, cephalosporins, and quinolones. The correct choice of antibiotics should be made only after antibiotic sensitivity testing.

Knowledge of the bacacterial pathogen of wound and the Antibiotic susceptibility pattern are important tools in the management of wound and are also useful in formulating balanced antibiotic policy.

\section{Recommendations}

This study recorded that Staphylococcus aureus and E.coliwere the most common organisms in wound infection. Meropinem and Levofloxacin were the most effective antimicrobial agents for this type of infections. Resistance due to inappropriate use of drugs is a common finding in our environment and medical staff \& the community must be educated regarding the rational use of antibiotics. In future, the occurrence and drug susceptibility pattern of wound infections should be done by including anaerobic bacteria, fungus and other micro-organism those can be important causes of wound infections.

\section{Acknowledgements}

The authors would like thankful for Arsho Advanced Medical Laboratory for allowing us to collect the sample and use the laboratory facilities.

\section{References}

[1] Esebelahie, N. O. Newton-Esebelahie, F. O. Omoregie R. Aerobic bacteria isolated from infected wound. African journal of clinical and expremental microbiology. 2013; 14(3):1595-689.

[2] Egbe CA, Omoregie R, Igbarumah IO, Onemu S. Microbiology of wound infections and its associated risk factors among patients of a Tertiary hospital in Benin City, Nigeria. JRHS. 2011; 11(2):109-113.

[3] Bowler PG, Duerden BI and Armstrong DG. Wound microbiology and associated approaches to wound management. Clinical Microbiology Review. 2001; 14:244269. 
[4] Sibor JO, Oseni A, Eyaufe A, Osagie R. Turay A. Incidence of aerobic bacteria and Candida albicas in post operative wound infections. Afr J Microbiol Res. 2008; 2:288-291.

[5] Aynalem Mohammed, Mengistu Endris Seid, Teklay Gebrecherkos, Moges Tiruneh, and Feleke Moges, "Bacterial Isolates and Their Antimicrobial Susceptibility Patterns of Wound Infections among Inpatients and Outpatients Attending the University of Gondar Referral Hospital, Northwest Ethiopia," International Journal of Microbiology, 2017, 2017; 10.

[6] Cheesbrough M. Microbiology: in Medical Laboratory Manual for Tropical countries. ELBS edition. University Press, Cambridge. 1999; 132: 26-58.

[7] Bauer, A. W., W. M. Kirby, J. C. Sherris and M. Turck. Antibiotic susceptibility testing by a standard single discmethod. American Journal Clinical Pathology. 1966; 45:493-496.

[8] Rao R, Basu R, Biswas DR. Aerobic Bacterial Profile and Antimicrobial Susceptibility Pattern ofPusIsolates in a South Indian Tertiary Care Hospital. IOSR-JDMS. 2014; 13(3):59-62.

[9] Bularafa Mohammed Yasidiet al:: Retrospective Analysis of Bacterial Pathogens Isolated from Wound Infections at a Tertiary Hospital in Nguru, Yobe State Nigeria.

[10] Khan I, Sarwar N, Ahmad B, Azam S, Rehman N Identification and Antimicrobial Susceptibility Profile of Bacterial Pathogens Isolated From Wound Infections in a Teaching Hospital, Peshawar, Pakistan. Adv. Life Sci. 2017; 5(1): 08-12.

[11] Karia JB, Gadekar HB, Lakhani SJ. Study of bacterial profile of pus culture in dhirajGeneralhospital. Indian, J. SurgOncol. 2013; 4(2):172-218.
[12] Shittu AO, Kolawole DO and Oyedepo EAR. A study ofwound infections in two health institutions in ile-ife, Nigeria. Afr. J. Biomed. Res. 2002; 5 (3): 97-102.

[13] Muluye D, Wondimeneh Y, Ferede G, Nega T, Adane K, Biadgo B, Tesfa H, Moges. Bacterial isolates and their antibiotic susceptibility patterns among patients with pus and/or wound discharge at Gondar University hospital. $B M C$ Research Notes. 2014; 7:619.

[14] [14] Daniel SJC, Gowthani DE, Sowmiya S. Isolation and identification of bcateril pathogens from wound of diabetic patients. Int. J. Curr, Microbiol. Appl. Sci. 2013; 2(11):72-77.

[15] Adane Bitew, Mesele Admassie, Tigist Getachew. Spectrum and Drug Susceptibility Profile of Bacteria Recovered from Patients with wound Infection Referred to Arsho Advanced Medical Laboratory. Clinical Medicine Research. 2018;7 (1): 8-17.

[16] Manikandan C. and Amsath A. Antibiotic susceptibility of bacterial strains isolated from wound infection patients in Pattukkottai, Tamilnadu. India Int. J. Curr. Microbiol. App. Sci. 2013; 2(6): 195-203.

[17] Syed AsadAli, S. M. Tahir, Abdul SattarMemon, Noshad A. Shaikh. Pattern of pathogens and their sensitivity isolated from superficial surgical site infections in a tertiary care hospital. JAyub Med Coll Abbottabad. 2009; 21(2).

[18] Agwunglefah, F. D., Nwabunike, C. C. and Nwaju, P. C. Antibiotic Susceptibility Pattern of Bacteria Isolated From Surgical Wounds of Patients Attending Federal Medical Center and Christiana Specialist Hospital, Owerri. Journal of Natural Sciences Research. 2014; 4(15): 2224-3186. 